\title{
Isolation and Characterization of Cyclodextrin Glucanotransferase from Soil Bacterium
}

\author{
R. Geetha and Sunil S. More \\ Department of Biochemistry, Centre for Post-Graduate Studies, Jain University, \\ 18/3, 9th Main Jayanagar Block III, 560-011 Bangalore, Karnataka, India
}

\begin{abstract}
An alkalophilic bacterium was isolated from the soil sample of sugar cane fields. A sterilized culture medium was prepared and the bacteria were grown for 6 days at $28^{\circ} \mathrm{C}$ in static condition at $\mathrm{pH} 10.5$. phenolphthalein assay was performed to confirm the presence of CGTase using soluble starch as substrate. The positive strain was identified based on morphological, physiological and biochemical tests and according to Bergey's manual as Bacillus alcalophilus AF078812. Time course of CGTase production was studied in shake flasks for 20 days with the maximum activity observed on the 6 th day. The enzyme was purified upto 44.06 fold by starch adsorption method with an yield of $6.4 \%$ and specific activity of $327 \mathrm{U} \mathrm{mg}^{-1}$. Among the starches examined, soluble starch was the best substrate. A low Km value $\left(0.02 \mathrm{mg} \mathrm{mL}^{-1}\right)$ suggested soluble starch as the preferred substrate to produce CDs with Vmax of $64.1 \mathrm{U} \mathrm{mg}^{-1}$ protein. The enzyme was a monomer with a molecular weight $28 \mathrm{kDa}$ estimated by SDS-PAGE. Enzyme activity was observed over a broad range of $\mathrm{pH}$ 4.5-8.5, optimum being 8.5. Alkaline CGTase exhibited thermostability for a longer duration at its optimum temperature $45^{\circ} \mathrm{C}$. SDS was found to be strong inhibitor of the enzyme wherein TLCK, NEM, IAA, DTT, TLCK and DAN has no effect on enzyme activity. Moderate inhibitory effect was seen with EDTA on CGTase, indicating it to be a metalloenzyme. Enhanced activity was observed in presence of activators like $\mathrm{Cu}^{+2}, \mathrm{Mn}^{+2}$, $\mathrm{Ca}^{+2}$ and $\mathrm{Fe}^{+2}$ whereas, $\mathrm{Mg}^{+2}$ and $\mathrm{Zn}^{+2}$ lowered it.
\end{abstract}

Key words: CGTase, Bacillus alcalophilus, alkalophilic CGTase, activity, soil sample, sugar cane

\section{INTRODUCTION}

The increasing interest centered around the alkaliphilic Bacillus species is in connection with a great impact that these alkaliphilic microorganisms have made by their valuable and commercially important enzymes (Horikoshi, 1999; Antranikian et al., 2005; Van den Burg, 2003). The alkaliphilic bacilli are the best producers of the enzyme cyclodextrin glucanotransferase (CGTase, EC 2.4.1.19). This enzyme is capable of converting starch and related substrates into cyclodextrins (CDs, cyclic $\alpha-1,4-$ glucans). The $\alpha-1,4$ linkage of the starch is retained to form a closed circular molecule, usually containing six, seven or eight glucose molecules.

These are referred to $\alpha-, \beta$ - and $\gamma$-forms of CD, respectively. These CDs are capable of association with a wide variety of molecules to form inclusion complexes. These complexes have altered chemical and physical properties that can introduce modified and often desirable properties, especially to the guest molecules such as altered solubility, volatility and chemical stability. These benefits have been of use in a wide variety of areas such as the food, chemical, pharmaceutical, analytical, diagnostic, cosmetic, agriculture and plastic industries and as stabilizing agents, emulsifiers, antioxidants and in other industrial areas (Cao et al., 2005).

The main advantage of enzymatic production is sterio, regio and chemoselectivity and specificity. Biotechnology processes may have potential in CDs production, specifically in special form of CD. This will depend on the screening of novel CGTases from Novel species which are able to produce specific form of CD in high yield at high productivity. Different CGTase enzymes produce a mixture of $\alpha$-, $\beta$ - and $\gamma$-CDs in different ratios. However, most CGTases produce $\beta-C D$ as the main product. CGTase producing primarily $\alpha$ and $\beta-\mathrm{CD}$ are relatively rare (Gawande and Patkar, 2001).

The $\beta$-form of $\mathrm{CD}$ is reported to be more suitable for industrial use since, inclusion complexes can be prepared easily and are very stable due to the low solubility of the $\beta$-CD in water. In addition, the yield of $\beta$-CD from starch is usually higher than that of the other CDs (Mahat et al., 2004). The $\beta-C D$ produced by CGTase depends on reaction conditions, substrate concentration amount of

Corresponding Author: Sunil S. More, Department of Biochemistry, Centre for Post-Graduate Studies, Jain University, 18/3, 9th Main Jayanagar Block III, 560-011 Bangalore, Karnataka, India 
enzyme and source of CGTase (Rha et al., 2005). To determine the optimal condition for $\beta$-CD production by CGTase, it is essential to understand the kinetics of the reaction. Until now, there have been several reports on factors affecting $\mathrm{CD}$ production by CGTases from various microorganisms (Kim et al., 1995; Charoenlap et al., 2004; Szerman et al., 2007). Some reports studied on the kinetics of CGTase but most of them focused only on the effect of substrate concentration ( Gawande and Patkar, 2001; Matioli et al., 2002; Moriwaki et al., 2007a). A novel Bacillus alcalophilus $\mathrm{AF} 078812$ strain producing alkaline CGTase was isolated and considering the diverse industrial applications of the enzyme, the aim of the present study was to produce, purify and characterize CGTase.

\section{MATERIALS AND METHODS}

Microorganisms: Soil samples from the fields cultivating potatoes, pumpkin, corn and cane were collected in the harvesting season of each crop along Kanakpura road. The soil surrounding the roots of the plant was used for preparation of the inoculum $(1 \mathrm{~g}$ in $10 \mathrm{~mL}$ distilled water). The soil samples were maintained in hydrated condition throughout to prevent inactivation of CGTase producing organism. These were analyzed in order to isolate strains of CGTase producing bacteria.

Rapid screening: For the fast screening of CGTase test, Horikoshi' medium (II9) was modified which contained: $5 \%$ soluble starch, $0.5 \%$ peptone, $0.5 \%$ yeast extract, $0.02 \% \quad \mathrm{MgSO}_{4} .7 \mathrm{H}_{2} \mathrm{O}, \quad 0.1 \% \quad \mathrm{~K}_{2} \mathrm{HPO}_{4}, \quad 0.02 \%$ phenolphthalein, $0.01 \%$ methyl orange, $1.5 \%$ agar, $1 \%$ $\mathrm{Na}_{2} \mathrm{CO}_{3}$. Nutrient agar components ( $\mathrm{pH} 7$ and 10.5 each) were mixed and autoclaved at $15 \mathrm{psi}$ for $15 \mathrm{~min}$. The liquid agar was poured into five petriplates at $\mathrm{pH} 7$ and 10.5, respectively and allowed to solidify and labeled.

Samples of $1 \mathrm{~g}$ of soil were suspended in $10 \mathrm{~mL}$ of sterile distilled water. After soil sedimentation, $0.1 \mathrm{~mL}$ of the supernatant was spread using a sterile glass spreader on the surface of a plate containing culture media. The plates were incubated at $37^{\circ} \mathrm{C}(24-48 \mathrm{~h})$. Development of CGTase producing organism was confirmed by presence of a clear yellowish halo around the bacterial culture. These colonies were selected for further examination (Salva et al., 1997).

Characterization of organism: The organism was characterized based on the morphological, physiological and biochemical tests and Bergey's manual of determinative bacteriology (Higuti et al., 2003).

Culture medium: Selected bacterial colonies were subcultured and pure culture was obtained. A sterilized culture medium was prepared which contained $2 \%$ soluble starch, $0.5 \%$ peptone, $0.5 \%$ yeast extract, $0.02 \%$ $\mathrm{MgSO}_{4} .7 \mathrm{H}_{2} \mathrm{O}$ and $0.1 \% \mathrm{~K}_{2} \mathrm{HPO}_{4}$ and the bacteria were grown for 6 days at $28^{\circ} \mathrm{C}$ at static condition in a New Brunswick rotatory shaker at $\mathrm{pH} 10.5$ (Salva et al., 1997).

Enzyme assay: The cells were removed by spinning and the supernatant that contained the enzyme was assayed.

Dextrinizing activity assay: It was performed using soluble corn starch as substrate and by measurement of the decrease in iodine-staining power (Salva et al., 1997). The reaction medium contained $0.1 \mathrm{~mL}$ of the enzyme solution, $0.5 \mathrm{~mL}$ of $1 \%$ starch solution, $0.4 \mathrm{~mL}$ of $0.1 \mathrm{M}$ phosphate bufffer, $\mathrm{pH} 7.0$ and incubated in a water bath at $50^{\circ} \mathrm{C}$ for $10 \mathrm{~min}$. The reaction terminated with $0.5 \mathrm{~mL}$ of $1 \mathrm{M} \mathrm{HCl}, 0.1 \mathrm{~mL}$ of $4 \mathrm{mM}$ iodine in $30 \mathrm{mM}$ potassium iodide was added and then diluted to $3.4 \mathrm{~mL}$ with water. The absorption by starch-iodine complex was read at $620 \mathrm{~nm}$ against a suitable blank. Further, phenolphthalein assay was performed to confirm the presence of CGTase only and to rule out the possibility of any other enzymes.

Phenolphthalein assay: The assay (Kaneko et al., 1987) was carried out using soluble starch as substrate and decrease in the intensity of pink colour of phenolphthalein was measured. Greater reduction in colour is the direct indication of CGTase activity as the enzyme forms inclusion complex with phenolphthalein. The reaction medium contained $0.1 \mathrm{~mL}$ of the enzyme solution, $0.5 \mathrm{~mL}$ of $4 \%$ starch solution, $0.9 \mathrm{~mL}$ of $0.1 \mathrm{M}$ phosphate buffer, $\mathrm{pH} 7.0$ and incubated at room temperature for $5 \mathrm{~min}$. It was then incubated in a water bath at $60^{\circ} \mathrm{C}$ for $15 \mathrm{~min}$. Immediately, $4 \mathrm{~mL}$ of $0.04 \mathrm{mM}$ phenolphthalein in sodium carbonate solution was added. The absorption was read at $550 \mathrm{~nm}$ against a suitable blank.

Time course of CGTase production: The strain was propagated in agar slants containing two soluble starch, 0.5 yeast extract, 0.5 peptone and $2 \%$ agar and incubated at $37^{\circ} \mathrm{C}$ for $48 \mathrm{~h}$. A loopful of cells was transferred into $50 \mathrm{~mL}$ of the selected minimal medium and incubated at $37^{\circ} \mathrm{C}$ for $24 \mathrm{~h}$ at $100 \mathrm{rpm}$. This culture was used as inoculum. Time course of CGTase production was studied in shake flasks for 20 days. A $1 \%(\mathrm{v} / \mathrm{v})$ inoculum, grown as described above was transferred in $250 \mathrm{~mL}$ Erlenmeyer flasks and incubated in the same conditions. At least duplicate experiments were run for each tested condition. Samples were removed periodically and cell growth, $\mathrm{pH}$ and CGTase activity were determined in each sample as stated earlier. 
Protein assays: Lowry et al. (1951) is a reasonably sensitive method for detecting down to $10 \mu \mathrm{g} \mathrm{cm}^{-3}$ of protein and the sensitivity is moderately constant from one protein to another $0.2-1.0 \mathrm{~mL}$ aliquots of standard BSA ( $\left.200 \mu \mathrm{g} \mathrm{mL}^{-1}\right)$ solution were made up to $1 \mathrm{~mL}$ with distilled water. About $10 \mu \mathrm{L}$ of filtrate was taken and diluted to $1 \mathrm{~mL}$ with distilled water. To the above tubes $5 \mathrm{~mL}$ of alkaline copper reagent was added and incubated for $10 \mathrm{~min}$ at room temperature. About $0.6 \mathrm{~mL}$ of $1: 2$ diluted FC reagent was then added to the tubes and incubated for $30 \mathrm{~min}$ at room temperature. Absorbance was read at $660 \mathrm{~nm}$ against a suitable blank.

A graph of $\mathrm{A}_{660}$ versus concentration of protein was plotted and extrapolated to obtain the protein concentration of the filtrate.

Partial purification of enzyme: The culture filtrate was first filtered and centrifuged at $10000 \mathrm{rpm}$ for $10 \mathrm{~min}$ to remove all cells. The supernatant was then subjected to ammonium sulfate precipitation. The precipitate obtained was pelleted by centrifugation and resuspended in a minimum quantity of buffer and dialyzed. The dialyzed sample was used for further studies.

Enzyme purification: The dialyzed enzyme sample solution $(150 \mathrm{~mL})$ was mixed with $3 \%$ starch and ammonium sulfate at $20 \%$ saturation at $4^{\circ} \mathrm{C}$ for $60 \mathrm{~min}$ with gentle stirring. The CGTase that was adsorbed on to the starch was collected by centrifugation $(4000 \times \mathrm{g}$ for $20 \mathrm{~min}$ at $4^{\circ} \mathrm{C}$ ) and washed twice with $10 \mathrm{mM}$ phosphate buffer $\mathrm{pH}$ 7.0. The enzyme was extracted with a $1 \mathrm{mM}$ solution of $\beta$-cyclodextrin in $10 \mathrm{mM}$ phosphate buffer, $\mathrm{pH} 7.0$, under mechanical stirring at $37^{\circ} \mathrm{C}$ for $30 \mathrm{~min}$. This material was centrifuged $\left(10000 \times \mathrm{g}\right.$ for $10 \mathrm{~min}$ at $\left.4^{\circ} \mathrm{C}\right)$ and the supernatant dialyzed during $18 \mathrm{~h}$ against $10 \mathrm{mM}$ phosphate buffer, $\mathrm{pH} 7.0$ at $4^{\circ} \mathrm{C}$ (Ferrarotti et al., 1996).

\section{Biochemical characterization \\ The hydrolysis percentages of different starches (Slide test): About $1 \mathrm{~mL}$ of $2 \%$ gelatinised samples of potato starch, corn starch, soluble starch, amylopectin, $\alpha$-cyclodextrin and $\beta$-cyclodextrin were prepared separately. The hot gelatinized samples were poured, spreaded on a clean glass slide and allowed to solidify. About $20 \mu \mathrm{L}$ of crude enzyme was poured in a hole made in the middle using gel punch. The slides were kept overnight in separate petridishes, over wet filterpaper (to avoid cracking of the solidified gel). About $1 \mathrm{~mL}$ of $0.04 \mathrm{mM}$ phenolphthalein in sodium carbonate solution was poured to visualize the clear zones (Shelby, 1993).}

SDS PAGE: SDS-PAGE was performed with $12 \%$ gel at $(\mathrm{pH} \mathrm{8.3)}$ by the method of Laemmli (1970). After electrophoresis, the proteins were visualized by Coomassie brilliant blue staining.
Effect of pH on activity and stability of alkaline CGTase: The influence of $\mathrm{pH}$ on CGTase activity was studied colourimetrically. Starch was used as substrate to determine the optimum $\mathrm{pH}$ of CGTase. The $\mathrm{pH}$ optima was determined over a range of 3-10 using citrate buffer (3 and 4), acetate (4.5-5.5), phosphate buffer (6-7), Tris buffer (7.5-8.5) and borate buffer (9 and 10) of $0.2 \mathrm{M}$ strength each. The effect of $\mathrm{pH}$ on the activity of CGTase was measured by incubating $0.1 \mathrm{~mL}$ of enzyme and $1 \mathrm{~mL}$ of buffers $(\mathrm{pH} 3,4,4.5,5.5,6,7,7.5,8.5,9$ and 10 ), containing $4 \%$ soluble starch and activity was determined by phenolphthalein assay.

Stability of the enzyme at optimum $\mathrm{pH}$ value was also studied by incubating the enzyme at that $\mathrm{pH}$ for different intervals of time and estimating the residual activity.

Effect of temperature on activity and stability of alkaline CGTase: The influence of temperature on CGTase activity was studied calorimetrically. Starch was used as substrate to determine the optimum temperature of CGTase. The optimum temperature was determined over a range of $0-100^{\circ} \mathrm{C}$ using phosphate buffer of $\mathrm{pH} 7.0,0.1 \mathrm{~mL}$ of partially purified enzyme and $0.5 \mathrm{~mL}$ of $4 \% \mathrm{starch}, 4 \mathrm{~mL}$ of $0.04 \mathrm{Mm}$ phenolphthalein in sodium carbonate were used, the total reaction mixture being $5.5 \mathrm{~mL}$ in phosphate buffer of $\mathrm{pH}$ 7.0. Absorbance $-\mathrm{A}_{550}$ was read against a suitable blank. Thermostability was determined by incubation of crude enzyme at temperatures ranging from $37-70^{\circ} \mathrm{C}$ for different intervals of time and estimating the residual activity.

Effect of different group specific reagents on the activity of alkaline CGTase: The effect of known concentration of group specific reagents on the enzyme activity was carried out with PMSF (Phenyl methane sulphonyl fluoride), DTT (Dithiothreitol), IAA (Indole Acetic Acid), N-acetyl imidazole, NEM (N-ethyl Malamide), NAI (Sodium azide), DAN, SDS (Sodium Dodecyl sulphate), Urea, TLCK (Tocyl Chloride methyl Ketone) and EDTA (Ethylene diamine tetra acetic acid) with the same substrate and all the conditions were same as mentioned for the normal activity of the CGTase.

Effect of metal ions on the activity of alkaline CGTase: The effect of metal ions on the activity of partially purified alkaline CGTase was determined by adding different metal ions in the reaction system. The divalent cations were $\mathrm{CuSO}_{4}, \mathrm{FeSO}_{4}, \mathrm{CaCl}_{2}, \mathrm{MgSO}_{4}, \mathrm{ZnSO}_{4}$ and $\mathrm{MnSO}_{4}$. These were added to the enzyme and pre incubated for $5 \mathrm{~min}$. The enzyme activity was determined by adding starch substrate according to the above mentioned procedure.

Kinetic parameters: The $\mathrm{Km}$ and Vmax values for the pure enzyme were determined by incubating $0.1 \mathrm{~mL}$ purified CGTase with starches (soluble, potato, corn and 
tapioca) at different concentrations $\left(2-20 \mathrm{mg} \mathrm{mL}^{-1}\right)$ in $1 \mathrm{~mL}$ of $0.1 \mathrm{M}$ phosphate buffer $(\mathrm{pH} 7.0)$. The assay was performed according to the standard enzyme assay method. Km and Vmax values were determined from Lineweaver and Burk (1934) while the kinetic constant Kcat was determined by the method of (Englard and Singer, 1950).

\section{RESULTS AND DISCUSSION}

Fast screening of CGTase producing organisms: Screening of alkaline CGTase producing organism from different soil samples of potato, pumpkin, bean, corn and cane sugar was performed by serial dilution method and spread plate method. The clear yellow hallow ring with red background on the phenolphthalein methyl orange plate indicated the development of positive CGTase producing bacterial strain. Among the 5 soil samples, the organism isolated from cane sugar soil sample showed very good dextrinizing activity as well CGTase activity.

Time course of CGTase production: Time course of CGTase production was studied in shake flasks for 20 days. Samples were removed periodically and cell growth, $\mathrm{pH}$ and CGTase activity were determined. Maximum activity was observed on the 6th day by the enzymes of bacteria isolated from the different soil samples. Figure 1 based on the morphological, physiological and biochemical tests the CGTase producing bacterium was tentatively identified as Bacillus alcalophilus AF078812.

The purified CGTase showed $327 \pm 2$ units $\mathrm{mg}^{-1}$ of specific activity with a $44.06 \pm 0.5$ fold purity. A final yield of $6.4 \%$ was achieved (Table 1 ).

The hydrolysis percentages of different starches (Slide test): Hydrolysis of different substrates such as soluble starch, corn starch, potato starch and amylopectin was observed against $\beta$ - and $\alpha$-cyclodextrin as controls. Appearance of clear zone around the region of enzyme in various slides indicated the degree of substrate specificity in terms of hydrolysis percentage of substrates. The partially purified alkaline CGTase showed the highest specificity towards soluble starch with $100 \%$ relative activity.

Potato and corn starches exhibited comparatively low relative activities whereas amylopectin did not produce CD's (Table 2).

SDS-PAGE: CGTase was found to be a monomer which was further confirmed by both reduced and non reduce

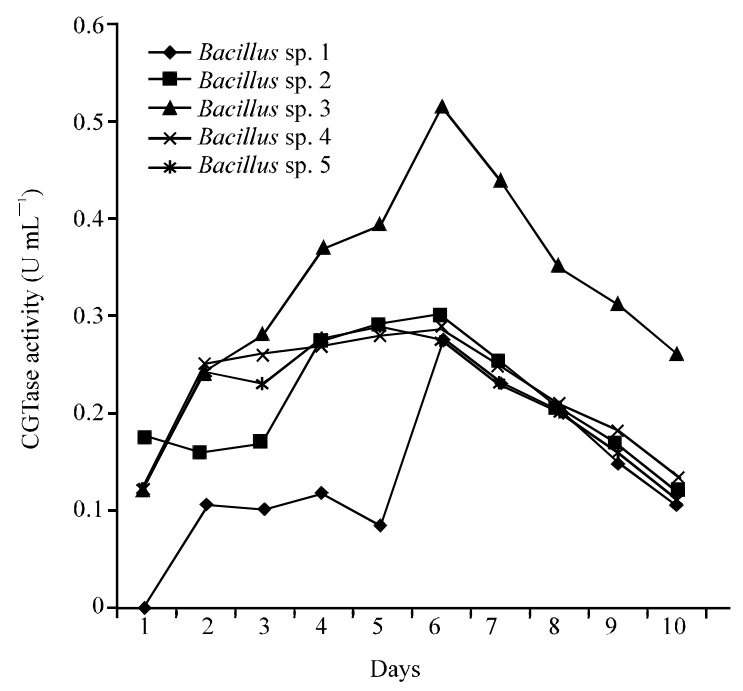

Fig. 1: CGTase activity of bacteria isolated from different soil samples

\begin{tabular}{|c|c|c|c|c|c|c|}
\hline Steps & $\begin{array}{l}\text { Volume } \\
(\mathrm{mL})\end{array}$ & $\begin{array}{l}\text { Total } \\
\text { protein } \\
(\mathrm{mg})\end{array}$ & $\begin{array}{c}\text { Total } \\
\text { unit }\end{array}$ & $\begin{array}{l}\text { Specific } \\
\text { activity } \\
\left(\mathrm{U} \mathrm{mg}^{-1}\right)\end{array}$ & $\begin{array}{c}\text { Purification } \\
\text { fold }\end{array}$ & $\begin{array}{r}\text { Yield } \\
(\%)\end{array}$ \\
\hline Crude enzyme & 150 & 114.0 & 2587 & 21 & 1.00 & 100 \\
\hline Starch adsorption & 34 & 2.1 & 1140 & 327 & 44.06 & 6.4 \\
\hline
\end{tabular}

Table 2: Substrate specificity of alkaline CGTase

\begin{tabular}{lc}
\hline Substrates & Relative activity (\%) \\
\hline Corn starch & 86.5 \\
Soluble starch & 100.0 \\
Potato starch & 88.4 \\
Amylopectin & 0.0 \\
\hline
\end{tabular}

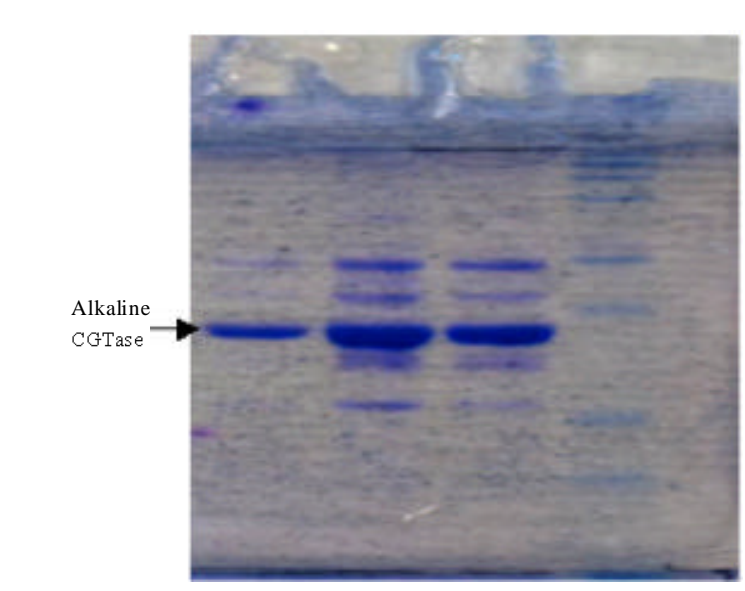

Fig. 2: CGTase monomer confirmed by both reduced and non-reduced PAGE of partionlly purified enzyme with a relative molecular weight of $28 \pm 1 \mathrm{kD}$ as estimated using standard molecular weight markers

PAGE of the partially purified enzyme with a relative molecular weight of $28 \pm 1 \mathrm{kD}$ as estimated using standard molecular weight markers (Fig. 2). The molecular weight was calculated by plotting callibration curve (Fig. 3 ). 
Res. J. Biol. Sci., 5 (10): 699-707, 2010

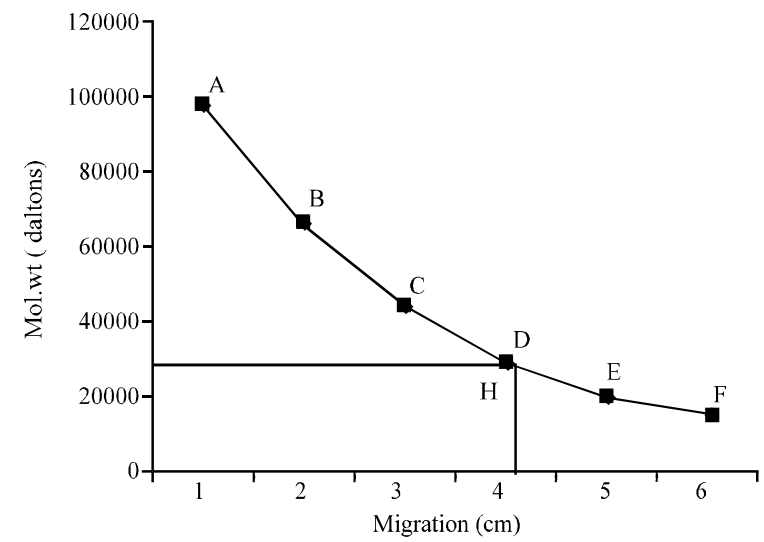

Fig. 3: SDS PAGE callibration curve

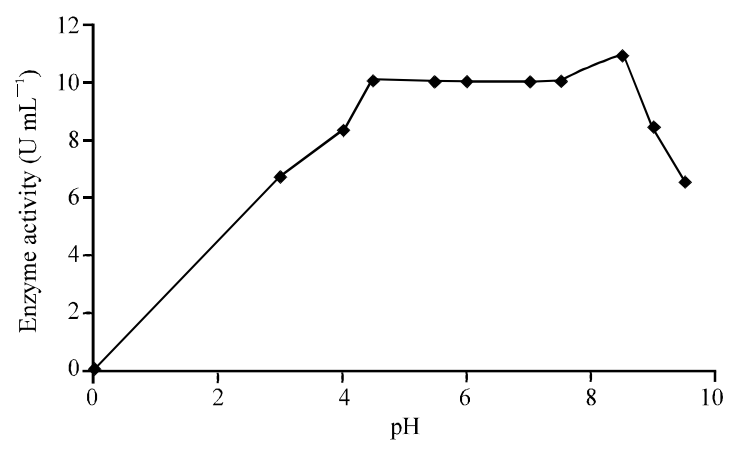

Fig. 4: Effect of $\mathrm{pH}$ on alkaline CGTase

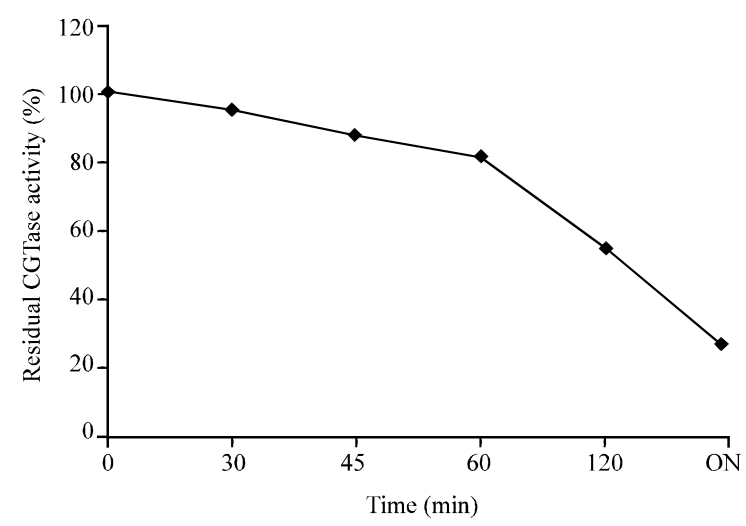

Fig. 5: pH stability

Effect of $\mathrm{pH}$ on the activity of alkaline CGTase and $\mathrm{pH}$ stability: Effect of $\mathrm{pH}$ on enzyme activity was measured by incubating reaction mixture at $\mathrm{pH} 3-10$, under standard conditions. The enzyme was active up to $\mathrm{pH}$ range from 4.5-8.5 (Fig. 4). The optimum $\mathrm{pH}$ for partially purified alkaline CGTase was observed at 8.5 (Fig. 5).

Effect of temperature on the activity of alkaline CGTase and thermostability: Effect of temperature on enzyme activity was measured by incubating the reaction mixture

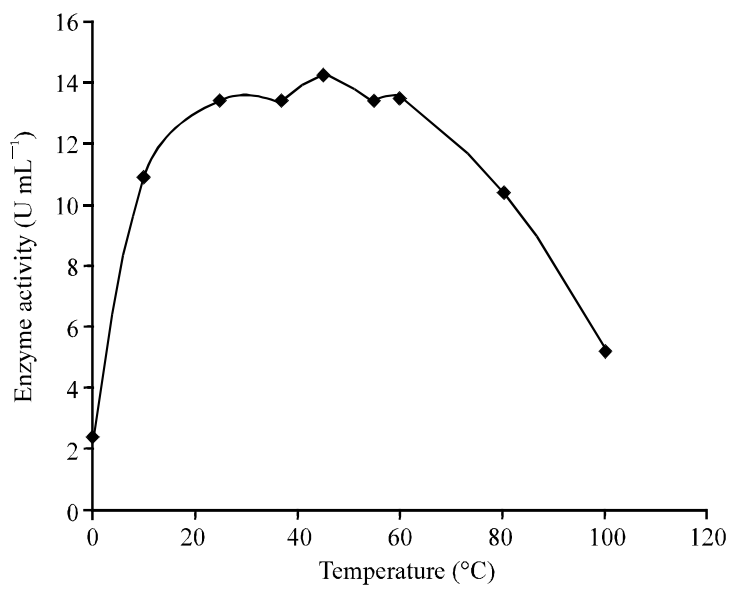

Fig. 6: Effect of temperature using enzyme activity

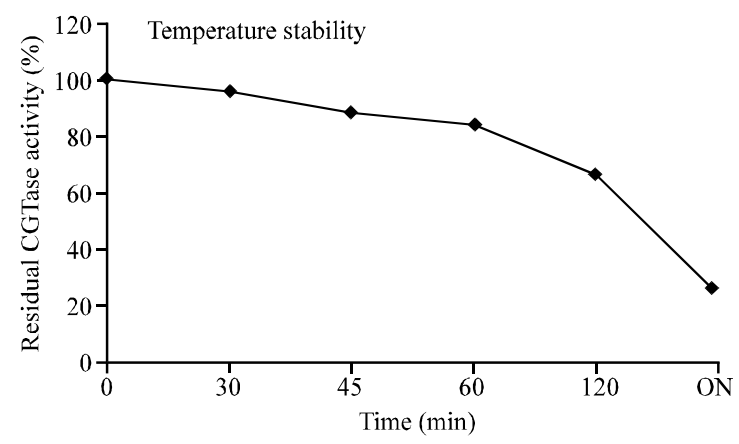

Fig. 7: The purified enzyme was observed to be stable for $2 \mathrm{~h}$ whereas overnight incubation showed 50\% reduction in enzyme activity

at $0,10, \mathrm{RT}, 37,45,55,60,80$ and $100^{\circ} \mathrm{C}$. Optimum temp was observed at $45^{\circ} \mathrm{C}$ (Fig. 6). The thermostability of the purified enzyme was studied at $45^{\circ} \mathrm{C}$ and at $\mathrm{pH} 8.5$. The purified enzyme was observed to be stable for $2 \mathrm{~h}$ whereas overnight incubation showed $50 \%$ reduction in enzyme activity (Fig. 7).

Effect of group specific reagents on CGTase activity: Various group specific reagents have been studied to detect their effect on the activity of the enzyme. NAI, $\mathrm{N}$-acetyl imidazole and IAA had no effect on the purified CGTase whereas, DTT, PMSF, Urea and TLCK had moderately affected. SDS was found to be a strong inhibitor (Fig. 8).

Effect of divalent cations on CGTase activity: Alkaline CGTase activity was measured in presence of various divalent cations such as $\mathrm{Cu}^{+2}, \mathrm{Fe}^{+2}, \mathrm{Ca}^{+2}, \mathrm{Mg}^{+2}, \mathrm{Mn}^{+2}$ and $\mathrm{Zn}^{+2}$ (Fig. 9). Alkaline CGTase activity was dependent on certain divalent metal ion activators like $\mathrm{Cu}^{+2}, \mathrm{Mn}^{+2} \mathrm{Ca}^{+2}$ and $\mathrm{Fe}^{+2}$. On the contrary, its activity reduced in presence of certain divalent metal ion inhibitors like $\mathrm{Mg}^{+2}$ and $\mathrm{Zn}^{+2}$. 
Res. J. Biol. Sci., 5 (10): 699-707, 2010

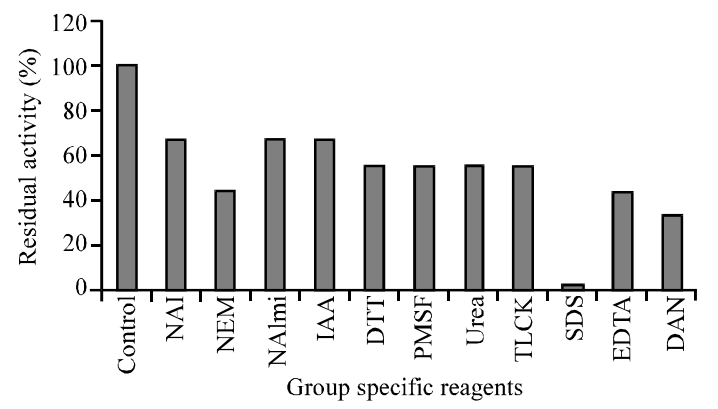

Fig. 8: SDS as a strong inhibition

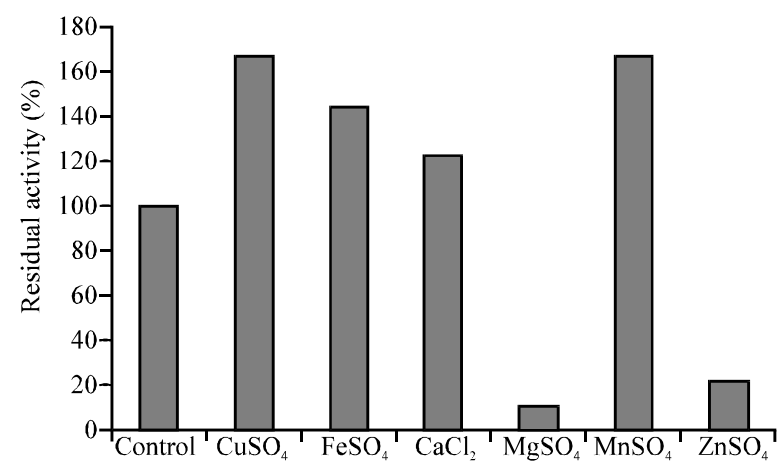

Fig. 9: Alkaine CGTase activity measured in presence of various divalent cations

Kinetic parameters of the alkaline CGTase: The kinetic parameter $\mathrm{Km}$ for alkaline CGTase was calculated as $0.02 \mathrm{mg} \mathrm{mL} \mathrm{m}^{-1}$ when soluble starch was used as the substrate. The low $\mathrm{Km}$ value indicates that the enzyme possesses a relatively high affinity towards soluble starch, compared to potato starch, corn starch and amylopectin (Table 3).

In the present investigation a positive CGTase producer bacterium was isolated from the soil sample and was characterized based on the morphological, physiological and biochemical tests and was tentatively identified as Bacillus alcalophilus AF078812. This finding is in agreement with the earlier reports by Biwer et al. (2002). Gawande and Patkar (1999), Goel and Nene (1995) and Tonkova (1998) also reported that CGTases are predominantly extracellular enzymes, produced by a variety of bacteria, mainly by Bacillus but also by Klebsiella, Micrococcus, Thermoanaerobacterium and others.

A modified Horikoshi's medium containiong soluble starch and both peptone and yeast as complex nitrogen sources at alkaline $\mathrm{pH}(10.5)$ was used which resulted in a better growth than with Nutrient Broth (NB). A similar medium was used in a study carried out by Kumar $(2010 \mathrm{a}, \mathrm{b})$ on $B$. licheniformis where in the microorganism presented growth at alkaline $\mathrm{pH}$.
Table 3: Kinetic parameters

\begin{tabular}{lcc}
\hline Types & $\mathrm{Km}\left(\mathrm{mg} \mathrm{mL}^{-1}\right)$ & Vmax $(\mathrm{mg} \mathrm{CD} / \mathrm{mL} / \mathrm{min})$ \\
\hline Soluble starch & 0.02 & 64.10 \\
Potato starch & 0.38 & 56.50 \\
Corn starch & 0.17 & 57.50 \\
Amylopectin & 0.47 & 45.21 \\
\hline
\end{tabular}

These data are similar to those of Bacillus alkalophilics which requires initial $\mathrm{pH} 9.0$ for the production of CGTase as reported by (Uitdehaag et al., 1999). Several authors reported variable CGTase yields, depending on strain, medium composition and culture conditions (Gawande and Patkar, 1999; Sabioni and Park, 1992a, b; Makela et al., 1990)

Time course of CGTase production studied for a period of 20 days resulted in the maximum activity on the 6 th day. This finding holds good with studies carried out by Rosso et al. (2002) on Bacillus circulans where in CGTase production increases sharply between 24 and $48 \mathrm{~h}$.

The partially purified alkaline CGTase showed the highest specificity towards soluble starch with $100 \%$ relative activity. Potato and corn starches exhibited comparatively low relative activities whereas amylopectin reported nil. This observation is concordant with the results obtained by Moriwaki et al. (2009) wherein highest activities of CGTase from Bacillus sphaericus were found on hydrolyzed starches, corn-starch, cassava starch and potato starch.

CGTase was found to be a monomer which was further confirmed by both reduced and non reduced PAGE of the partially purified enzyme with a relative molecular weight of $28 \pm 1 \mathrm{kD}$ as estimated using standard molecular weight markers. The result is in well accordance with studies by Savergave et al. (2008) on Bacillus firmus wherein the purified enzyme showed a single band by SDS-PAGE and molecular mass of CGTase was estimated as $76 \mathrm{kDa}$. Molecular mass of the previously purified CGTases from B. firmus was reported to be $80 \mathrm{kDa}$ by Sohn et al. (1997). Moriwaki et al. (2009) reported that the purified enzyme from Bacillus sphaericus gave a single protein band by SDS-PAGE and the molecular mass was estimated to be $59 \mathrm{kDa}$.

Majority of CGTase enzymes so far studied are found to possess a high molecular mass. This is the 1 st time a low molecular mass alkaline CGTase from Bacillus alcalophilus AF078812 is being reported. The optimum $\mathrm{pH}$ for partially purified alkaline CGTase was found to be 8.5 with the highest activity $\left(10.881 \mathrm{U} \mathrm{mL}^{-1}\right)$. This was also shown by Salva et al. (1997) with Bacillus circulans. The stability of the enzyme was studied by incubating the reaction mixture at optimum $\mathrm{pH} 8.5$ for different durations such as 30 and $45 \mathrm{~min}, 1$ and $2 \mathrm{~h}$ and overnight. 
After incubation for $2 \mathrm{~h}$ at $\mathrm{pH} 8.5$, enzyme activity was retained upto $55 \%$. Overnight incubation of enzyme at $\mathrm{pH}$ 8.5 lost $75 \%$ activity. Thus, the crude alkaline CGTase of Bacillus sp. seems to be active at alkaline $\mathrm{pH} 8.5$ suggesting it to be alkalotolerant. A relatively single broad peak of optimum $\mathrm{pH}$ activity has been reported by other researchers like Larsen et al. (1998), Liebl et al. (1992), Yong et al. (1996) and Yim et al. (1997) suggested a different degree of ionization of the enzyme catalytic site in order to produce the different cyclodextrins.

Highest activity of $14.229 \mathrm{U} \mathrm{mL}^{-1}$ was observed at $45^{\circ} \mathrm{C}$ which marked the optimum temperature of alkaline CGTase. This data is in close agreement with that for the CGTase from Bacillus firmus reported at $\sim 60^{\circ} \mathrm{C}$. In some studies values have been reported over a broad range of temperature between 45 and $70^{\circ} \mathrm{C}$ (Salva et al., 1997; Liebl et al., 1992; Yim et al., 1997; Sabioni and Park, 1992a, b)

Alkaline CGTase was found to be thermostable for a relatively longer period of time at $45^{\circ} \mathrm{C}$. These observations are in close agreement with the study by Moriwaki et al. (2009) on CGTase from Bacillus sphaericus wherein they reported that enzyme activity was retained upto $4 \mathrm{~h}$ at $50^{\circ} \mathrm{C}$ under alkaline $\mathrm{pH} 8.0$.

The inhibitory effect of some of the group specific reagents used in the research closely match with the studies carried out by Tiwari et al. (2007) on Pencillium rugulosum $\alpha$-amylase wherein they reported that EDTA and SDS inhibited the activity of $\alpha$-amylase. Also in a study carried out by Chang et al. (1995), $\alpha$-amylase from Aspergillus oryzae ATCC 76080 was reported to be inhibited by NAI ( $6 \mathrm{mM})$.

The observations of increased bacterial cell growth but decreased alkaline CGTase activity using $\mathrm{Mg}^{+2}$ and relatively high $\%$ residual activity in presence of $\mathrm{Ca}^{+2}$, $\mathrm{Cu}^{+2}, \mathrm{Mn}^{+2}$ and $\mathrm{Fe}^{+2}$ match closely with those of Gawande and Patkar (1999), Jin-Bong et al. (1990), Tomita et al. (1993) and Thatai et al. (1999) wherein they found that magnesium was found to be essential for bacterial growth and iron for CGTase production in the case of Bacillus firmus, Bacillus stearothermophilus, Bacillus autolyticus and a Bacillus sp., respectively. CGTase from Bacillus autolyticus exhibited $92 \%$ of relative activity when $2 \mathrm{mM}$ $\mathrm{CuSO}_{4}$ was used (Tomita et al., 1993).

However, the inference drawn with $\mathrm{Zn}^{+2}$ exhibiting inhibitory effect from the study differs with that of Thatai et al. (1999) in that $\mathrm{Zn}^{2+}$, a known inhibitor enhanced the activity by $150 \%$. The effect of metal ions on CGTase activity seems to depend on the enzyme source (Yim et al., 1997; Sabioni and Park 1992b; Fujita et al., 1990). Thatai et al. (1999) reported that the presence of $\mathrm{CaCl}_{2}$ increased the production of CGTase. In most cases, calcium ions are needed to stabilize CGTase at higher temperature where it will react as a protective agent but are not involved in increasing the reaction rate of the enzyme.

The low $\mathrm{Km}$ value indicates that the enzyme possesses a relatively high affinity towards soluble starch, compared to potato starch, corn starch and amylopectin. This finding holds good with results obtained by Moriwaki et al. (2007b), Matioli et al. (2001) and Moriwak et al. (2009) wherein they reported that the $\mathrm{Km}$ value for the pure enzyme were $0.0011 \mathrm{~mol} \mathrm{~L}^{-1}$, $0.0033 \mathrm{~mol} \mathrm{~L}^{-1}$ and $0.00299 \mathrm{~mol} \mathrm{~L}^{-1}$ from B. firmus strain 7B, B. firmus strain 37 and B. sphaericus, respectively. Rahman et al. (2006) also reported a low value of $\mathrm{Km}$ for CGTase from an alkalophilic Bacillus sp. suggesting a high affinity for the substrate.

\section{CONCLUSION}

In the present investigation a positive CGTase producing bacterium from soil sample was screened and identified as Bacillus alcalophilus AF078812 based on the morphological, physiological and biochemical tests. It was found to be an alkolophilic strain which can be a potential source for the large scale production of CGTase. The enzyme can be used to synthesize linear oligosaccharides and their derivatives by its coupling and disproportionation reactions. It has been shown that CGTase can use a variety of carbohydrates and other compounds as acceptors in the reactions. The synthesis of a number of glycosylated compounds by CGTase has been reported.

For example, CGTase catalyzes the glycosylation of stevioside, thereby decreasing the bitterness of the compound and increasing its solubility. The alkaline $\mathrm{pH}$ was very efficient for solubilizing neohesperidin and a high yield of glycosides could be obtained. Since, alkaline CGTases have high commercial value, the enzyme can be immobilized and used repeatedly for many cycles.

Further, isolating the gene and expressing it in some other organism for maximal production or by mutations in order to get better yield of CGTase attracts industrially important biotechnological applications in terms of its product's characteristic properties.

CDs have a unique molecular structure consisting of a truncated cone with a hydrophobic cavity. Due to this characteristic property, CDs are able to form inclusion complexes with a wide variety of hydrophobic guest molecules. The physiochemical properties of this guest 
molecule such as solubility in water, chemical stability and bioavailability can therefore be modified. As a result, CDs are widely used in the pharmaceutical, food, agriculture and cosmetic industries.

\section{REFERENCES}

Antranikian, G., C.E. Vorgias and C. Bertoldo, 2005. Extreme environments as a resource for microorganisms and novel biocatalysts. Adv. Biochem. Eng. Biotechnol., 96: 219-262.

Biwer, A., G. Antranikian and E. Heinzle, 2002. Enzymatic production of cyclodextrins. Applied Microbiol. Biotechnol., 59: 609-617.

Cao, X., Z. Jin, X. Wang and F. Chen, 2005. A novel cyclodextrin glycosyltransferase from an alkalophilic Bacillus species: Purification and characterization. Food Res. Int., 38: 309-314.

Chang, C.T., M.S. Tang and C.S. Lin, 1995. Purification and properties of \&alpha-amylase from Aspergillus oryzae ATCC 76080. Biochem. Molbiol. Int., 36: 185-193.

Charoenlap, N., S. Dharmsthiti, S. Sisisansaneeyakul and S. Lertsiri, 2004. Optimization of cyclodextrin production from sago starch. Bioresour. Technol., 92: $49-54$.

Englard, S. and T.P. Singer, 1950. Physiochemical studies on \&alpha-amylase. J. Biol. Chem., 187: 213-219.

Ferrarotti, S.A., A.M. Rosso, M.A. Maréchal, N. Krymkiewicz and L.R. Marechal, 1996. Isolation of two strain (S-R Type) of Bacillus circulans and purification of a cyclomaltodextrin-glucano transferase. Cell Mol. Biol., 42: 653-657.

Fujita, Y., H. Tsubouchi, Y. Inagi, K. Tomita, A. Ozaki and K. Nakanishi, 1990. Purification and properties of cyclodextrin glycosyltransferase from Bacillus sp. AL-6. J. Fermentation Bioeng., 70: 150-154.

Gawande, B.N. and A.Y. Patkar, 1999. Application of factorial designs for optimization of cyclodextrin glycosyltransferase production from Klebsiella pneumoniae AS-22. Biotechnol. Bioeng., 64: 168-173.

Gawande, B.N. and A.Y. Patkar, 2001. Purification and properties of a novel raw starch degradingcyclodextrin glycosyltransferase from Klebsiella pneumoniae AS-22. Enzyme Microb. Technol., 28: 735-743.

Goel, A. and S. Nene, 1995. A novel cyclomaltodextrin glucanotransferase from Bacillus firmus that degrades raw starch. Biotechnol. Lett., 17: 411-416.

Higuti, I.H., S.W. Grande, R. Sacco and A.J. Nascimento, 2003. Isolation of alkalophilic CGTaseproducing bacteria and characterization of cyclodextringlycosyltransferase. Braz. Arch. Biol. Tech., 46: 183-186.
Horikoshi, K., 1999. Alkaliphilies: Some applications of their products for biotechnology. Microb. Molecul. Biol. Rev., 63: 735-750.

Jin-Bong, H., S.H. Kim, T.K. Lee and H.C. Yang, 1990. Production of maltodextrin from Bacillus stearothermophilus. Korean J. Applied Biotechnol., 19: $578-584$.

Kaneko, T., T. Kato, N. Nakamura and K. Horikhoshi, 1987. Spectrophotometric determination of cyclozation activity of â-cyclodextrin-forming cyclodextrin glucanotransferase. J. Japan Soc. Starch Sci., 34: 45-48.

Kim, T.J., B.C. Kim and H.S. Lee, 1995. Production of cyclodextrin using moderately heat-treated corn starch. Enzyme Microb. Technol., 17: 1057-1061.

Kumar, V., 2010a. Analysis of the key active subsites of glycoside hydrolase 13 family members. Carbohydrate Res., 345: 893-898.

Kumar, V., 2010b. Identification of the conserved spatial position of key active-site atoms in glycoside hydrolase 13 family members. Carbohydr Res., 345: 1564-1569.

Laemmli, U.K., 1970. Cleavage of structural proteins during the assembly of the head of bacteriophage $T_{4}$. Nature, 227: 680-685.

Larsen, K.L., L. Duedahl-Olesen, H.J.S. Christensen, F. Mathiesen, L.H. Pedersen and W. Zimmermann, 1998. Purification and characterization of cyclodextrin glycosyltransferase from Paenibacillus sp. F8. Carbohydr. Res., 310: 211-219.

Liebl, W., R. Feil, J. Gabelsberger, J. Kellermann and H.H. Schleifer, 1992. Purification and characterization of a novel thermostable 4-alpha-glucanotransferase of Thermotoga maritima cloned in Escherichia coli. Eur. J. Biochem., 207: 81-88.

Lineweaver, H. and D. Burk, 1934. The determination of enzyme dissociation constants. J. Am. Chem. Soc., 56: 658-666.

Lowry, O.H., N.J. Rosebrough, A.L. Farr and R.J. Randall, 1951. Protein measurement with folin phenol reagent. J. Biol. Chem., 193: 265-275.

Mahat, M.K., R.M. Illias, R.A. Rahman, N.A.A. Rashid and N.A.N. Mahmood et al., 2004. Production of cyclodextrin glucanotransferase (CGTase) from alkalophilic Bacillus sp. TS1-1: Media optimization using experimental design. Enzyme Microb. Technol., 35: 467-473.

Makela, M.J., S.K. Paavilainen and T.K. Korpela, 1990. Growth dynamics of cyclodextrin glucanotransferase producing Bacillus circulans var. alkalophilus. Can. J. Microbiol., 36: 176-182. 
Matioli, G., G.M. Zanin and F.F. Moraes, 2001. Characterization of cyclodextrin glycosyltransferase from Bacillus firmus strain no. 37. Appl. Biochem. Biotechnol., 91: 93-643.

Matioli, G., G.M. Zanin and F.F. Moraes, 2002. Influence of substrate and product concentrations on the production of cyclodextrins by CGTase of Bacillus firmus, strain no. 37. Appl. Biochem. Biotechnol., 98-100: 947-960.

Moriwaki, C., G.L. Costa, R. Pazzetto, G.M. Zanin, F.F. Moraes, M. Portilho and G. Tioli, 2007a. Production and characterization of a new cyclodextrin glycosyltransferase from Bacillus firmus isolated from Brazilian soil. Process Biochem., 42: 1384-1390.

Moriwaki, C., F.M. Pelissari, R.A.C. Goncalves, J.E. Goncalves and G. Matioli, 2007b. Immobilization of Bacillus firmus strain 37 in inorganic matrix for cyclodextrin production. J. Mol. Catal., B Enzym, 49: 1-7.

Moriwaki, C., L.R. Ferreira, J.R.T. Rodella and G. Matioli, 2009. A novel cyclodextrin glycosyltransferase from Bacillus sphaericus strain 41: Production, characterization and catalytic properties. Biochem. Eng. J., 48: 124-131.

Rahman, K., R.M. Illias, O. Hassan, N.A.N. Mahmood and N.A.A. Rashid, 2006. Molecular cloning of a cyclodextrin glucanotransferase gene from alkalophilic Bacillus sp. TS1-1 and characterization of the recombinant enzyme. Enzyme Microb. Tech., 39: 74-84.

Rha, C.S., D.H. Lee, S.G. Kim, W.K. Min and S.G. Byun, 2005. Production of cyclodextrin by poly-lysine fused Bacillus macerans cyclodextrin glycosyltransferase immobilized on cation exchanger. J. Mol. Catal. B: Enzym, 34: 39-43.

Rosso, A.M., S.A. Ferrarotti, N. Krymkiewicz and B.C. Nudel, 2002. Optimisation of batch culture conditions for cyclodextrin glucanotransferase from Bacillus circulans DF 9R. Microl. Cell Fact., 1: 1-9.

Sabioni, J.G. and Y.K. Park, 1992a. Cyclodextrin glycosyltransferase production by alkalophilic Bacillus lentus. Rev. Microbiol., 23: 128-132.

Sabioni, J. and Y. Park, 1992b. Production and characterization of cyclodextrin glycosyltransferase from Bacillus lentus. Starch, 44: 225-229.

Salva, T.J.G., V.B. De Lima and A.P. Pagan, 1997. Screening of alkalophilic bacteria for cyclodextrin glycosyltransferase production. Rev. Microbiol., 28: 157-164.
Savergave, L.S., S.S. Dhule, V.V. Jogdand, S.N. Nene and R.V. Gadre, 2008. Production and single step purification of cyclodextrin glycosyltransferase from alkalophilic Bacillus firmus by ion exchange chromatography. Biochem. Eng. J., 39: 510-515.

Shelby, N.F., 1993. Purification and characterization of the extracellular alpha amylase from Streptococcus bovis JBI. Applied Environ. Microbiol., 59: 1398-1402.

Sohn, C.B., S.A. Kim, Y.A. Park, M.H. Kim, S.K. Moon and S.A. Jang, 1997. Char-acterization of cyclodextrin glycosyltransferase from Bacillus firmus. J. Korean Soc. Food Sci. Nutr., 26: 351-357.

Szerman, N., I. Schroh, A.L. Rossi, A.M. Rosso, N. Krymkiewicz and S.A. Ferrarotti, 2007. Cyclodextrin production by cyclodextrin glycosyltransferase from Bacillus circulans DF 9R. Bioresour. Technol., 98: 2886-2891.

Thatai, A., M. Kumar and K.J. Mukherjee, 1999. A single step purification process for cyclodextrin glucanotransferase from a Bacillus sp. isolated from soil. Preparat. Biochem. Biotechnol., 29: 35-47.

Tiwari, K.L., S.K. Jadhav and Fatima, 2007. Culture condition for the production of thermostable amylase by Penicillium rugulosum. Global J. Biotechnol. Biochem., 2: 21-24.

Tomita, K., M. Kaneda, K. Kawamura and K. Nakanishi, 1993. Purification and properties of a cyclodextrin glucanotransferase from Bacillus autolyticus 11149 and selective formation of â-Cyclodextrin. J. Ferment. Bioeng., 75: 89-92.

Tonkova, A., 1998. Bacterial cyclodextrin glucanotransferase. Enzyme Microbiol. Technol., 22: 678-686.

Uitdehaag, J.C.M., K.H. Kalk, B.A. van der Veen, L. Dijkhuizen and B.W. Dijkstra, 1999. The cyclization mechanism of cyclodextrin glycosyltransferase (CGTase) as revealed by a $\gamma$ cyclodextrin-CGTase complex at 1.8-A resolution. J. Biol. Chem., 274: 34868-34876.

Van den Burg, B., 2003. Extremophiles as a source for novel enzymes. Curr. Opin. Microbiol., 6: 213-218.

Yim, D.G., H.H. Sato, Y.H. Park and Y.K. Park, 1997. Production of cyclodextrin from starch by cyclodextrin glycosyltransferase from Bacillus firmus and characterization of purified enzyme. J. Ind. Microbiol. Biotechnol., 18: 402-405.

Yong, J., J.N. Choi, S.S. Park, C.S. Park, K.H. Park and Y.D. Choi, 1996. Secretion of heterologous cyclodextrin glycosyltransferase of Bacillus sp. E1 from Escherichia coli. Biotechnol. Lett., 18: 1223-1228. 